\title{
DSpace@MIT
}

\author{
MIT Open Access Articles
}

\section{An Engineering Review of the Farm Tractor's Evolution to a Dominant Design}

The MIT Faculty has made this article openly available. Please share how this access benefits you. Your story matters.

As Published: 10.1115/1.4042338

Publisher: ASME International

Persistent URL: https://hdl.handle.net/1721.1/135115

Version: Final published version: final published article, as it appeared in a journal, conference proceedings, or other formally published context

Terms of Use: Article is made available in accordance with the publisher's policy and may be subject to US copyright law. Please refer to the publisher's site for terms of use. 


\section{An Engineering Review of the Farm Tractor's Evolution to a Dominant Design}

\author{
Guillermo F. Díaz Lankenau' ${ }^{1}$ \\ Global Engineering and Research Laboratory, \\ Department of Mechanical Engineering, \\ Massachusetts Institute of Technology, \\ Cambridge, MA 02139 \\ e-mail: diazlank@mit.edu
}

\section{Amos G. Winter V \\ Global Engineering and Research Laboratory, Department of Mechanical Engineering, Massachusetts Institute of Technology, Cambridge, MA 02139 e-mail: awinter@mit.edu}

This paper explains the origin and merits of the dominant farm tractor design, which has endured since the 1940s. Understanding the origins and rationale for this dominant design enables engineers to appreciate its merits, and understand its drawbacks, which could be addressed in future designs. Additionally, the methods used in this paper to study tractor evolution are applicable to the study of other products with a longstanding dominant design. Two themes are covered in this paper: first, the historical context that directed the farm tractor's design evolution is presented; and second, a terramechanicsbased tractor model is used to analyze why the dominant design is conducive to good performance. The prominent characteristics of the dominant tractor design are its weight distribution, wheel layout, tool location, and construction. Its weight distribution maximizes drawbar pull by placing 70 to $80 \%$ of the total vehicle weight on the rear wheels. Shifting the weight forward reduces pulling force while shifting it backward produces a negligible increase in pulling capacity while dangerously increasing the risk of upending the tractor. The tractor has four wheels arranged in a rectangular pattern-the rear wheels are driven while the front ones are usually idle. Rear wheels are of large diameter to increase ground clearance and tractive efficiency. Front wheels are of small diameter to allow for a large steering angle despite a narrow track width. A narrow track width reduces the space required for making a U-turn at field ends and improves access to farm spaces. Inline front and rear wheels are desirable for ease of driving between rows and to best harness soil compaction. Attaching implements behind the rear axle leverages tillage forces to increase maximum drawbar pull and enables using large tools. The tractor's crankcase and transmission housing are structural components-this reduces mass and manufacturing complexity. [DOI: 10.1115/1.4042338]

\section{Introduction-The Importance of Farm Tractors}

Tractors are an icon of industrialized, modern farming, and their presence has been noted as a differentiator between farming in developed versus developing countries [1,2]. There is high correlation worldwide between farm productivity and available tractor power [1,3-5]. In 1950, the U.S. Census Bureau summarized the benefits of mechanizing American agriculture during the past 50 years [6]: mechanical power on farms influenced agriculture more than any other factor; mobile, powered farm equipment increased the rate at which farm work was done and has increased the capacity of agricultural workers, enabling considerable numbers of farm workers to leave the farms or to engage in nonfarm work; and tractors and power-operated equipment made an increase in the size of farms possible.

This paper provides historical and physics context for why the modern tractor evolved to its dominant design. This understanding and the analysis framework used to explain it are valuable tools for evaluating new tractor designs. The work presented herein is of contemporary relevance. Farm mechanization is growing in emerging markets and common pitfalls of engineers designing for those markets include poor assumptions about the needs of end users and a lack of knowledge about the specific problem space, cultural norms, and technical area [7]. This paper can help these engineers by supplying them with the context in which tractors were originally developed (and thus a reference point to compare to their target market) and by accelerating their development of expertise on farm tractors by understanding the underlying

\footnotetext{
${ }^{1}$ Corresponding author

Contributed by the Design Theory and Methodology Committee of ASME for publication in the Journal of Mechanical Design. Manuscript received June 30 , 2018; final manuscript received December 10, 2018; published online February 25, 2019. Assoc. Editor: Christopher Mattson.
}

physics. A historical background on tractor design can also help gain insights on new innovation opportunities; for example, relatively new autonomous driving and precision farming technologies encourage the development of novel tractor-like vehicle platforms [8]. Engineers may more confidently break away from the dominant tractor design if they understand its origins.

\section{History of Farm Tractor Evolution to a Dominant Design}

2.1 Design Features of the Conventional Farm Tractor. The conventional small tractor produced today found its form mostly in the U.S. between 1910 and 1940 [9-12]. The most salient features of the "conventional tractor" or "dominant tractor design" are:

- Four wheels laid out in a rectangular pattern, attached to front and rear axles.

- Pneumatic tires on all wheels, with the rear tires having larger diameter and width than the front tires.

- Front wheel steering.

- Rear-wheel drive with the wheels joined by a differential axle (front wheel assist sometimes present).

- Independently controlled braking force at each rear wheel (two brake pedals are provided).

- Engine rests over the front axle.

- Operator sits between both axles, usually only slightly ahead of rear axle.

- Trailing implement behind the rear axle, option to attach implement rigidly (via "Three-Point Hitch").

- Rear-pointing, engine-powered exposed shaft behind the rear axle for powering implements ("Power Take-Off" (PTO)).

- Engine crankcase and transmission case used as structural components. 


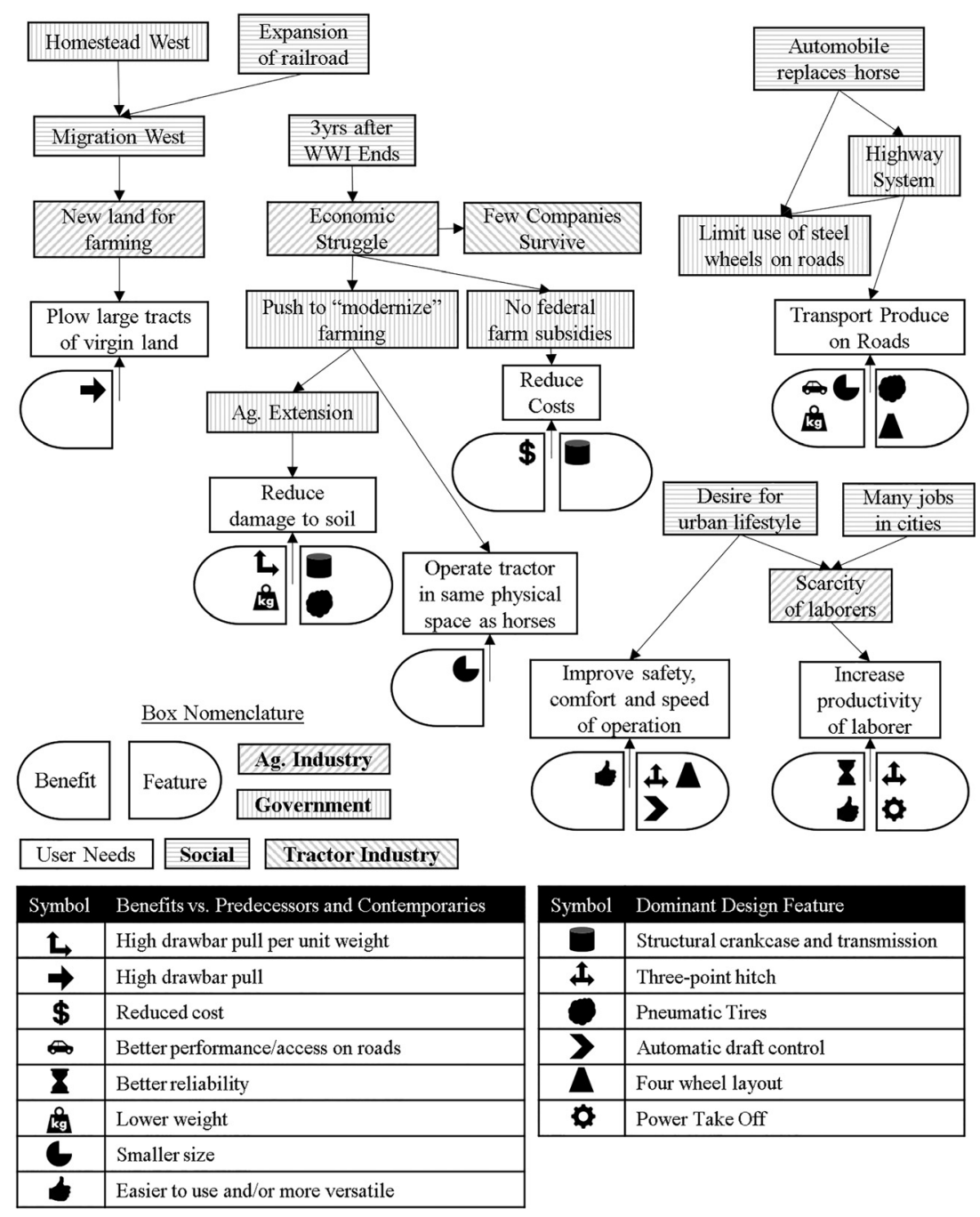

Fig. 1 Graphic chronology of tractor evolution as influenced by historical context and stakeholder expectations

Similar to many products, these characteristics did not evolve solely to improve farm field performance; they were also determined by pressure to lower manufacturing and distribution costs, improve marketability, increase versatility and ease of use, and comply with government regulations. Some of these pressures and their impacts are discussed in Secs. 2.2 and 2.3. They are also summarized in Fig. 1.

To emphasize the other design directions the nascent tractor industry could have taken, Fig. 2 shows 24 production tractor layouts from between 1910 and 1920. Layouts varied widely in traction gear (mostly combinations of tracks, wheels, and drums), number of axles, driver position, tool position, and overall dimensions.

Few of these designs would have a significant and lasting impact on the industry, however. Figure 3 highlights a selection of production tractors whose most salient features would influence future models and later become enduring characteristics of the dominant tractor design.

2.2 1900-1920: Early History of the Modern Farm Tractor. In 1903, the term "tractor" was first coined in advertisements by the Hart Parr Gasoline Engine company (Charles City, IA) of Charles City, IA. At the time, horses and mules were the primary source of draft power in the burgeoning American farming industry. In the U.S., the Homestead Act of 1862 was still ongoing with minor revisions and motivated farmers to extend westward from the northeastern cities. Earnest farmers tilled the wild soil and rapidly expanded the total amount of available arable land [9]. The large tractors (often steam powered) of the time were more capable than animals at tilling the expansive tracts of land in the Midwest prairies but were also unwieldy and expensive. These tractors were specialized tools aimed at heavy tillage of large areas and as mobile motors to power crop processing machines.

During the late 1910s, the agricultural industry in the U.S. became highly profitable as food exports increased dramatically to feed resource depleted Europe and Russia during and after World War I. Between 1915 and 1920, the agricultural output of Eastern Europe and Northwestern Europe dropped by half and a third, respectively [26]. During those five years, U.S. farms sold at almost continually rising prices that drove their net income to almost triple, and farmland prices to more than double, as farming became a more attractive investment [27,28]. American farms grew in number and size, yet farm labor was more scarce as the rural youth went to fight in WWI and later returned preferring an urban lifestyle. Farm tractors became an attractive way to multiply the capacity of each laborer [6].

The blooming tractor industry innovated quickly as it received feedback from a rapidly expanding customer base and adopted engineering knowledge from its younger but more refined cousin, the automobile [29]. It was often the case that the farmer who owned a tractor still had to own horses, which were more 


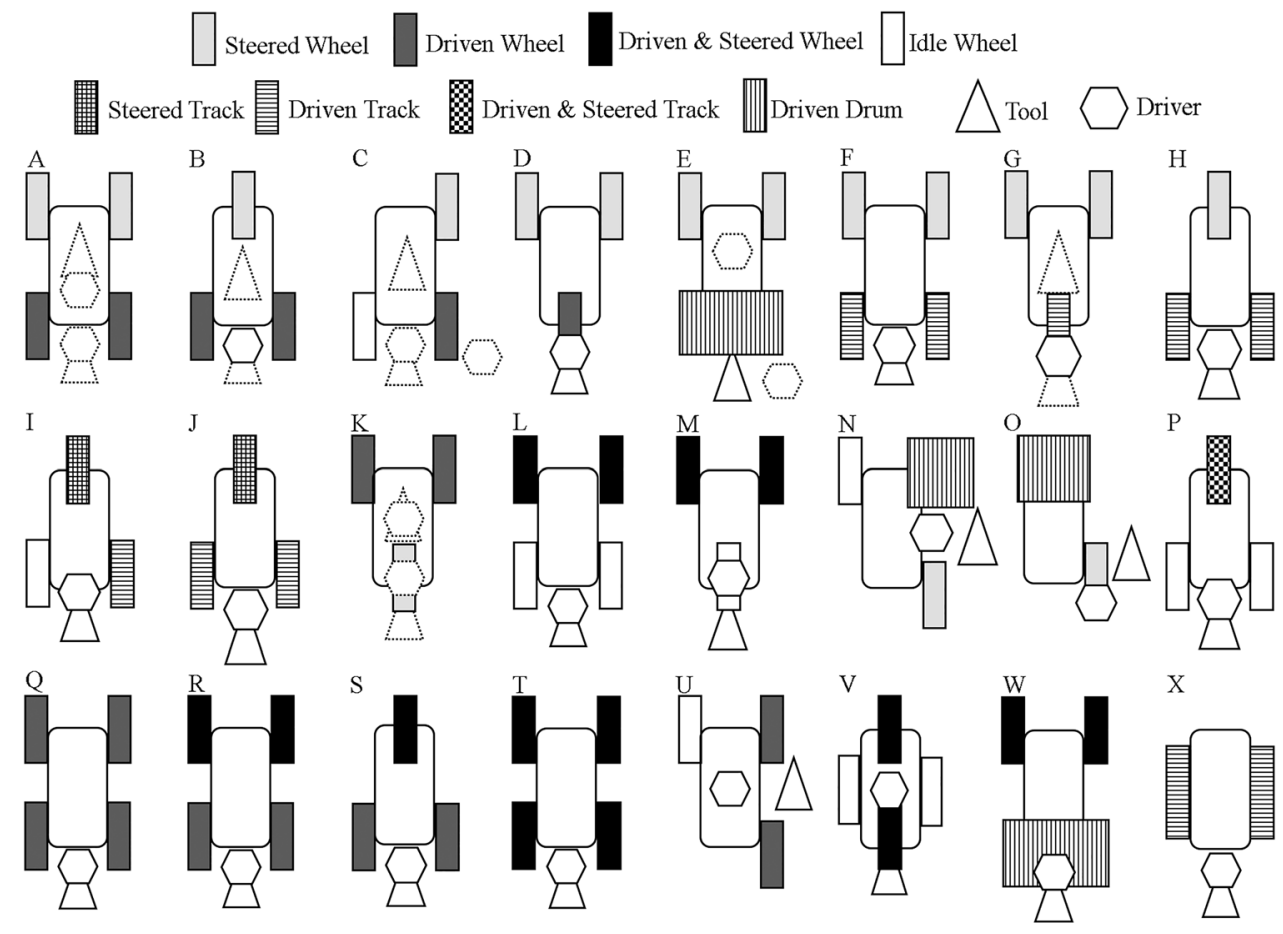

Fig. 2 Sample of tractor design layouts from 1910 to 1920 . Components with a dotted outline represent multiple possible locations in otherwise identical layouts. Designs $A-J$ are rear axle driven, $\mathrm{K}-\mathrm{P}$ are front axle driven, and Q-X are driven by both front and rear axles. A list of some production tractors using each layout can be found in Appendix A.

maneuverable and smaller, for cultivation operations [30,31]. Very large tractors that had been used to open large fields in the expanding West were too specialized and would lay rusting with little or no use after that initial heavy plowing operation [9,31]. The demand for a less expensive, smaller, and lighter tractor was growing, and manufacturers new and old rushed to fill the void $[32,33]$.

The first tractor to meet the demands of the common farmer in size and price was offered by the Bull Tractor Company (Minneapolis, MN) in 1913 (Fig. 3). This lightweight tractor had three wheels with a single drive-wheel and had an initial price comparable to a team of horses. By 1914, it was the best-selling tractor in the country [9]. The tractor industry still had reliability issues and production volume challenges that it would learn to solve partially from automobile experts becoming more involved. In 1917, Henry and Edsel Ford launched Fordson tractors (Detroit, MI). Their model F quickly became the best-selling tractor in the world and would eventually be produced at a price and volume that would raise the entry barrier to tractor manufacturing beyond what most smaller competitors could muster [9]. The Model F was already highly reminiscent of today's modern small tractor and also of the traditional automobile layout. It had four wheels, front wheel steering, rear wheel drive, and a trailing tool. Not yet incorporated were pneumatic tires, a rigid tool attachment system (three-point hitch), and an exposed engine-powered shaft for powering implements (power take-off).

2.3 1920-1950: Farm Tractors Converge on a Common Design to Power American Farms. In 1920, 166 companies in the U.S. manufactured farm tractors and had a combined annual production of 203,207 tractors. These were dramatic increases from 1910, when only 15 farm tractor companies were in business and had a combined production of 4000 tractors [34]. These 166 companies were competing to define the shape of the "farm tractor" and to distinguish themselves through innovative designs (a sample of tractor layouts is shown in Fig. 2) [29,30].
During 1921, a dramatic shift occurred in U.S. production. Agricultural output in Eastern and Northwestern Europe had quickly recovered to pre-WWI levels to suddenly make them largely independent of imported food [26]. Farmers in the U.S. had misjudged international demand and food overproduction caused the prices of agricultural produce to plummet. Farmers abruptly found themselves unprofitable and with outstanding bank loans used to purchase farmland that had since collapsed in value [28]. Farm tractor production plunged by two-thirds from 203,277 units in 1920 to 68,029 units in 1921 [34].

The Great Depression and Stock Market Crash of 1929 would keep American farmers in a difficult position through the 1920s and 1930s. It forced tractor manufacturers to adapt to a low cash flow style of farming. In February 1922, the "Tractor Price Wars" started when Fordson (a Ford Motor Co. brand) slashed the price of its popular Model F from $\$ 625$ to $\$ 395$ [9]. Over the next 20 years, a fiercely price-competitive tractor market would see manufacturers converge on similar designs. Many manufacturers would disappear in this "war," from 166 manufacturers in 1920 to only 38 in 1930 . However, the industry's annual tractor production had rebounded to 196,297 units in 1930 , very similar to the output of 1920 [34]. Yearly total production of American tractors would keep rising until reaching a peak in 1951, when 564,000 tractors were manufactured. By 1950, there were over 3.6 million tractors operating in American farms (about one tractor for every six people living on a farm) and the internal combustion engine had become the primary source of draft power for farmers [6].

Farm tractor production between 1910 and 1950 was significantly higher in the U.S. than elsewhere in the world. In any given year, production in the U.S. was at least ten times higher than any other single country, and at least five times greater than the net global production excluding the U.S. American tractors were in high demand domestically and also exported extensively [35]. 


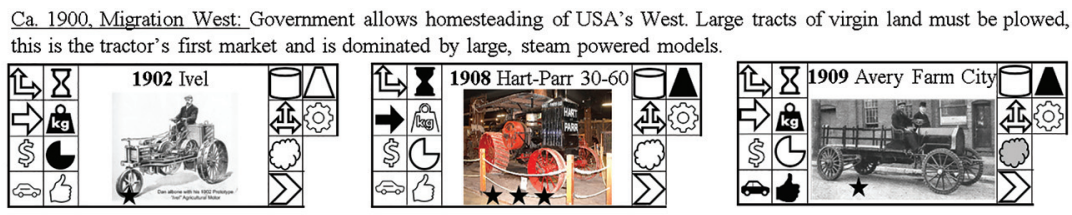

During and soon after WWI: American farming is highly profitable as produce is exported to Europe and Russia. Scarcity of laborers makes tractors an attractive option. Many tractor companies and designs emerge.

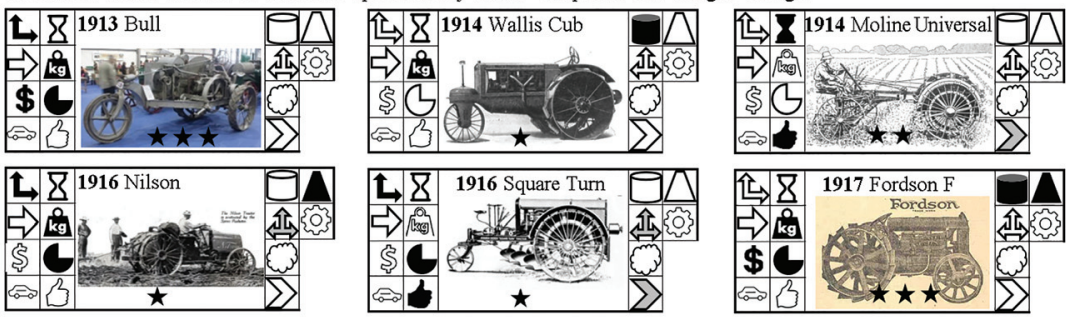

1920's crash: As foreign agriculture recovers, American produce exports plummet and national agriculture suffers. Low cash customers and a crashing national economy cause most tractor manufacturers to perish.
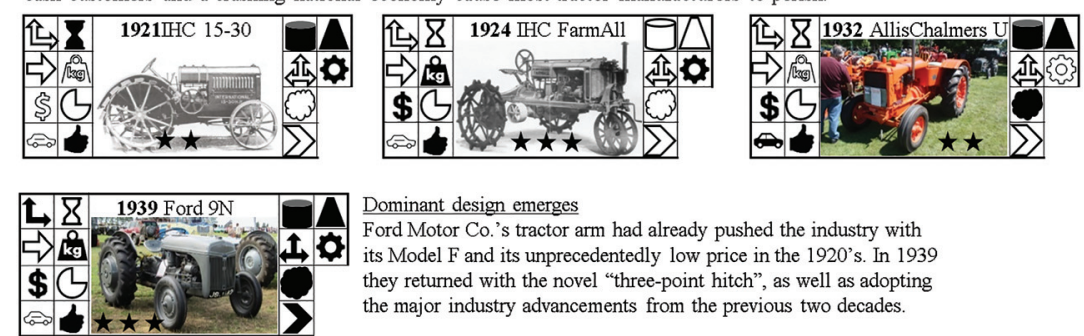

\begin{tabular}{|c|c|c|c|}
\hline Symbol & Advantages vs. predecessors and contemporaries & Symbol & Dominant Design Feature \\
\hline $\mathbf{t}$ & High drawbar pull per unit weight & & Structural crankcase and transmission \\
\hline & High drawbar pull & $\leftrightarrows$ & Three-point hitch \\
\hline$\$$ & Reduced cost & & Pneumatic Tires \\
\hline$\Leftrightarrow$ & Better performance/access on roads & & Automatic draft control \\
\hline & Better reliability & $\Delta$ & Four wheel layout \\
\hline $\mathrm{kg}$ & Lower weight & $\$$ & Power Take Off \\
\hline & Smaller size & \multirow{2}{*}{\multicolumn{2}{|c|}{$\begin{array}{l}\star \text { Low sales } \star \star \text { Average sales } \star \star \star \text { Sales leade } \\
\text { Feature is: } \square \text { absent } \square \text { evolving } \square \text { present }\end{array}$}} \\
\hline & Easier to use and/or more versatile & & \\
\hline
\end{tabular}

Fig. 3 Graphic chronology of tractor evolution into conventional small tractor design. Features whose evolving form appears much earlier than their final form may indicate a wide time span between the identification of a customer need and the availability of an adequate technology to satisfy it. More vehicle data and larger images are found in Appendix B. Photo credits: 1902 Ivel [13] (North Bedfordshire Gazette, 1903), 1908 Hart-Parr 15-30 [14] (H. Zell, Wikimedia Contributor, 2016), 1909 Avery Farm City [15] (The Horseless Age, 1909), 1913 Bull [16] (Bulldozer D11, tractors.wikia.com, 2008), 1914 Wallis Cub [17] (Farm Implement News Company, 1917), 1914 Moline Universal [18] (Gas Power, 1918), 1916 Nilson [19] (Country Gentleman Magazine, 1918), 1916 Square Turn [20] (Square Turn Tractor Company, 1916), 1917 Fordson F [21] (Wade and Dunton Motors, 1917), 1921 IHC 15-30 [22] (International Harvester Company, 1920), 1924 IHC FarmAll [23] (Edrob, tractors.wikia.com, 2010), 1924 Allis Chalmers U [24] (BulldozerD11, tractors.wikia.com, 2009), 1939 Ford 9N [25] (Charles01, Wikimedia Contributor, 2011).

2.4 Emergence of the Dominant Tractor Design Features Between 1910 and 1940. Major innovations that shaped the dominant tractor design and products that exemplified them are discussed below.

1914-The Wallis Cub (Fig. 3) was the first tractor to use the engine crankcase and transmission case as structural components. Launched in 1917, the Fordson F (Fig. 3) would leverage this construction style to reduce production costs by using less materials and more streamlined manufacturing than its competitors. The Fordson F's runaway success in domestic and international markets would help cement the structural crankcase and transmission as features of the dominant tractor design.

1916-The Square Turn (Fig. 3) featured innovations that signaled trends to come. The Square Turn's name boasts its ability to control both of its drive wheels independently for tight turning (even reversing one wheel while the other drives forward). The dominant tractor design that would emerge later features a differential axle and allows independent braking of either rear drive wheel for tight turning (a skilled driver may also use independent braking as a differential axle quasilock). The Square turn also used engine power for lowering and raising farming implements even while the tractor is stationary.

1921-All tractors sold in Nebraska must henceforth go through the standardized Nebraska Tractor Test, the results of which are public [36]. This test would go on to become the mandatory national, and later international, standard for tractor testing. For the manufacturers, outstanding performance in the test can 
provide a major marketing tool. Some of the more marketable results from the test involve towing a braked vehicle behind the tractor, an operation generally better suited to tractors designed to pull heavy tillage tools behind them.

1921-International Harvester introduces the PTO as an option in the 15-30 tractor (Fig. 3), allowing the tractor's engine to power actuators in farming implements through a rigid speedcontrolled shaft instead of using a flat belt. Implement manufacturers rush to take advantage of this innovation.

1925-International Harvester introduces its Farmall "General Purpose" tractor (Fig. 3). The Farmall series would become the best-selling tractor series ever in the U.S. Compared to most other tractors on the market, it was lighter, had higher ground clearance, utilized smaller front wheels (enabling tighter turns), had adjustable track width, and it was as advertised for cultivating, plowing, and cutting.

1932 - Firestone pneumatic tires are offered as standard equipment on the Allis Chalmers U (Fig. 3). Pneumatic tires allowed tractors on the growing network of paved roads (where steel, lugged wheel were not permitted) and enabled farmers to increase fuel efficiency and operate at higher speeds.

Circa 1935-Diesel engines are advanced enough to become standard in farm tractors [12]. This improves reliability (especially after storage periods), and gives the tractor a wider high-power rpm operating band.

1939-Ford and Ferguson introduced the three-point hitch tool mounting system in the Ford $9 \mathrm{~N}$ (Fig. 3). The system efficiently leverages draft forces from heavy tillage tools to improve the tractor's drawbar pull performance; a better implementation of the idea pioneered by the 1916 Nilson Tractor (Fig. 3). The $9 \mathrm{~N}$ featured hydraulic-powered coarse and fine control over implement vertical position, reducing the drudgery of tractor driving and tool attachment while also increasing the tractor's field capacity (actual acres worked per hour). The three-point hitch is the standard today for mounting trailing farming implements.

\section{Analytical Modeling of the Conventional Tractor's Design}

Insights into success of the conventional tractor design are elucidated by modeling its performance and then exploring the effects of altering the design. The modeling of a tractor on soil can be separated into two inter-related parts: calculating the distribution of forces among all tires (the tires hold the tractor afloat and propel it forward) and, given that load distribution, calculating the power consumption and other performance metrics at each individual tire. A detailed description of modeling off-road vehicles in uneven terrain can be found in Ref. [37].

3.1 Conventional Tractor Dimensions and Relevant Forces. Calculation of the tractor-applied forces at the tire-soil interface requires a force balance of the tractor and farm implement system. Under the assumption of the tractor being a laterally symmetric rigid body, being in steady-state equilibrium, and all the wheels having their rotation axes orthogonal to gravity and parallel to each other, the tractor free-body diagram (Fig. 4) can be simplified to include only:

- overall center of mass location and magnitude

- draft tool force direction, magnitude, and origin (center of pressure)

- location of ground reaction force points and associated vectors

- tractor orientation with respect to gravity (uphill or downhill slope)

Overall, the sum of the vertical force $V_{f}$ on the front wheels is

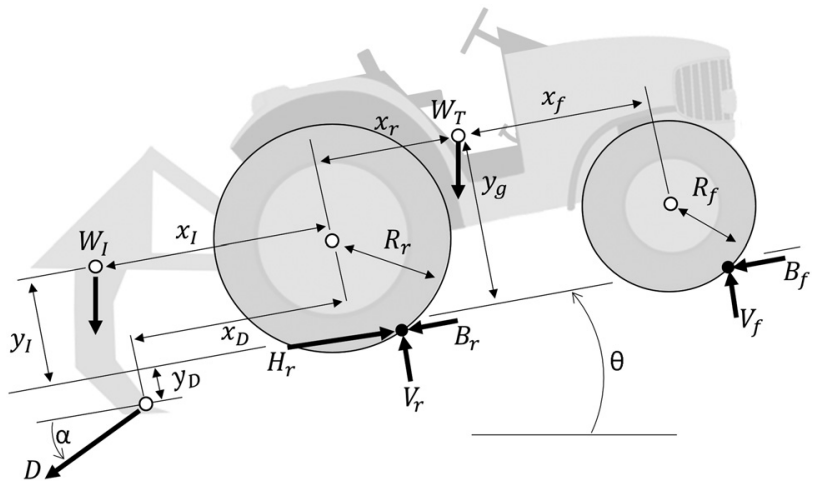

Fig. 4 Free body diagram for farm tractor in 2D

$$
\begin{aligned}
V_{f}= & \frac{1}{x_{f}+x_{r}}\left(W_{T}\left(x_{r} \cos (\theta)-y_{g} \sin (\theta)\right)\right. \\
& +D\left(y_{D}+\cos (\alpha)-x_{D} \sin (\alpha)\right) \\
& \left.+W_{I}\left(-x_{I} \cos (\theta)-y_{I} \sin (\theta)\right)\right)
\end{aligned}
$$

and the sum of the vertical force $V_{r}$ on the rear wheels is

$$
\begin{aligned}
V_{r}= & \frac{1}{x_{f}+x_{r}}\left(W_{T}\left(x_{r} \cos (\theta)+y_{g} \sin (\theta)\right)\right. \\
& +D\left(-y_{D}+\cos (\alpha)+x_{D} \sin (\alpha)\right) \\
& \left.+W_{I}\left(\left(x_{I}+x_{r}+x_{f}\right) \cos (\theta)+y_{I} \sin (\theta)\right)\right)
\end{aligned}
$$

where $x_{f}$ is the distance from the tractor center of gravity (CG) to the front axle, $x_{r}$ is the longitudinal distance from the tractor CG to the rear axle, $W_{T}$ is the weight of the tractor, $\theta$ is the ground slope angle, $y_{g}$ is the distance from the CG to the ground, $D$ is the tillage force, $y_{D}$ is the depth of the tillage tool center of pressure, $x_{D}$ is the longitudinal distance from the tillage tool center of pressure to the rear axle, $\alpha$ is the angle of the drawbar force vector relative to the ground slope, $W_{I}$ is the weight of the implement, $x_{I}$ is the longitudinal distance from the rear axle to the tillage tool $\mathrm{CG}$, and $y_{I}$ is the distance from the ground to the tillage tool CG.

It is assumed in the conventional tractor configuration that only the rear wheels are driven. To move the tractor forward at a constant speed, the rear tires must provide the net horizontal force

$$
H_{r}=B_{f}+B_{r}+D \cos (\alpha)+\left(W_{T}+W_{I}\right) \sin (\theta)
$$

where $B_{f}$ is the force from the soil on the front wheel opposing vehicle forward motion, $B_{r}$ is the force from the soil on the rear wheel opposing vehicle forward motion, $D$ is the tillage force, $W_{T}$ is the weight of the tractor, and $W_{I}$ is the weight of the implement.

The calculation of the actual wheel torque necessary to achieve $H_{r}$ and the calculation of resistance forces $B_{f}$ and $B_{r}$ requires further analysis described in Sec. 3.3.

3.2 Qualitative Description of Importance of Soil-Tire Interaction in Tractor Design. A refined terramechanic design can reduce the power lost at the soil-tire interfaces, something especially critical for farm tractors, which seek to minimize fuel consumption and damage to soil. While drivetrain mechanical losses in a small tractor can be under 5\%, power conversion at the tire-soil interface usually involves losses of 30 to $60 \%$ [38].

The two major causes of power loss are soil deformation and slippage at the tire-soil interface [39]. The effects of soil deformation from wheeled vehicles are observed in the ruts they leave behind. As the wheel rolls forward it deforms soil ahead of it (known as "bulldozing"). This deformation requires energy but achieves no useful work. Slippage occurs when the tangential speed 
of the tire contact is faster than the forward speed of the vehicle. Presence of at least minimal slippage is unavoidable as for a thrust force to occur the tire must exert a shear force on the soil (therefore causing soil deformation). When the shear strength of the soil is low relative to the traction being generated, the shear stress may result in large shear deformation and thus higher slippage.

An efficient terramechanic design must strike a balance between sinkage and slippage. The amount of power lost to slippage and bulldozing are both correlated to ground pressure, but usually with opposite effects $[39,40]$. As ground pressure increases, the shear strength of soils with a frictional component (most natural soils) increases, and thus less shear deformation is provoked by a given shear stress. This reduces slippage and energy losses provoked by it. On the other hand, as the ground pressure increases so does the sinkage of the tire into the soil, which results in more energy lost to bulldozing.

3.3 Model for Interaction of a Single Drive Tire With Soil. The tire-soil model summarized here is an implementation of that described by Wong [39], which is commonly accepted in terramechanics.

For analytically studying the tire-soil interface, it is helpful to investigate it as a 2D system and separate the net stress into normal stress (normal to the wheel perimeter) and shear stress (tangent to wheel perimeter). All weight-bearing wheels generate a normal stress on the soil. Only braked or powered wheels
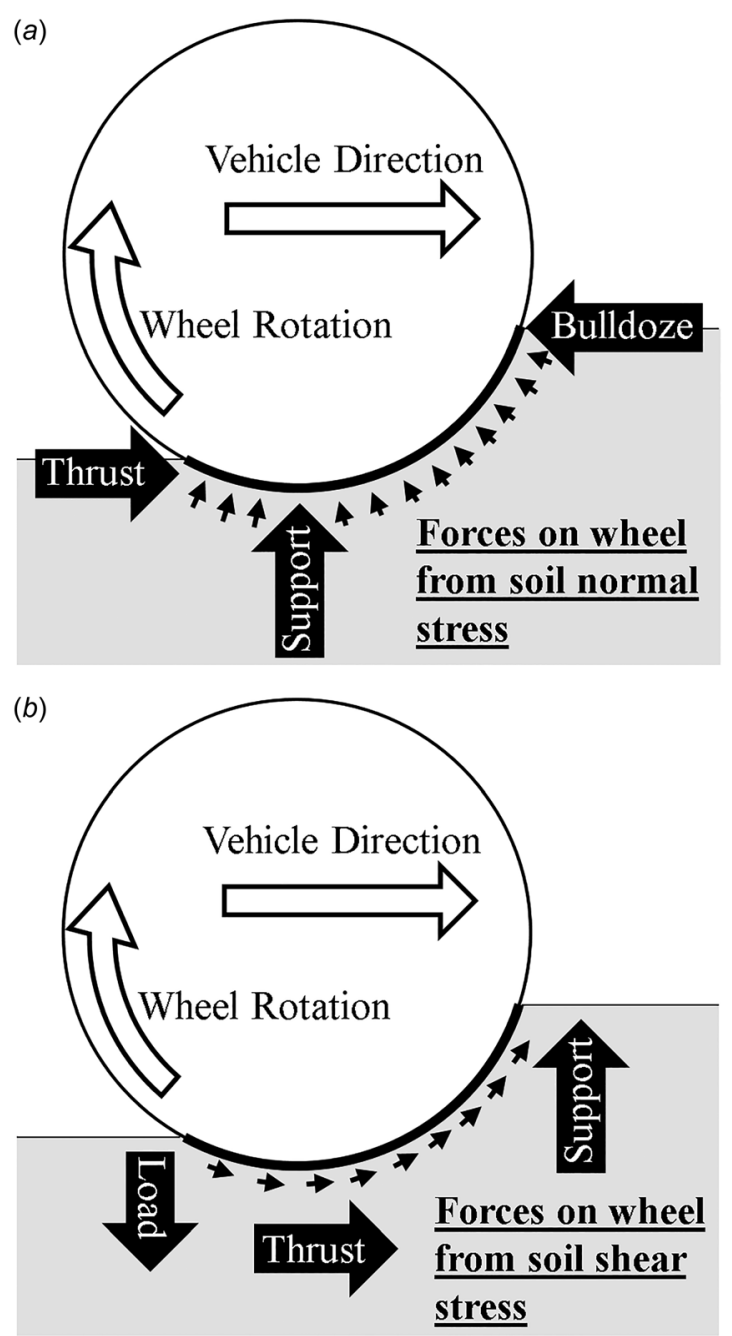

Fig. 5 Stress under rigid driven wheels rolling on deformable soil. Stress at the tire-soil interface is separated for clarity into normal (a) and shear (b). Wheels are moving to the right and rolling clockwise. Nomenclature according to reaction force direction (as felt by wheel) is shown in soil. generate significant shear stress on the soil. In Fig. 5 stress distributions at the soil-tire interface are shown for a rigid, smooth wheel in a homogeneous soil. Note that the soil is deformed plastically, as the wheel moves through it and thus the soil surface is lower behind the wheel than ahead of it.

In agricultural soils, the pressure required to penetrate into the ground increases with depth. Soil pressure as a function of depth is commonly expressed in terramechanics using Bekker's [41] or Reece's equations [42]. Reece's equation is used in this analysis because its soil constants are not a function of tire contact patch size. The resulting equation for soil pressure is

$$
p=\left(c k_{c}^{\prime}+w \gamma_{s} k_{\phi}^{\prime}\right)(z / w)^{n}
$$

where $p$ is soil normal stress, $c$ is soil cohesion, $k_{c}^{\prime}$ is the cohesion constant, $w$ is tire width, $\gamma_{s}$ is the soil bulk density, $k_{\phi}^{\prime}$ is the friction constant, $z$ is the depth below the soil surface, and $n$ is the depth exponent (an experimental value relating penetration depth to penetration resistance).

The shear strength of frictional soil increases with pressure, and the pressure exerted by soil increases with depth. This means that a wheel operating while sunk in soil may be interacting with different soil shear strengths along its perimeter. The soil strength can be reasonably predicted by the Mohr-Coulomb shear strength equation as a function of normal pressure

$$
s=(c+p \tan (\phi))\left(1-e^{-j(i) / k}\right)
$$

where $s$ is the soil shear stress, $p$ is the soil normal stress, $c$ is the soil cohesion, $\phi$ is the soil friction angle, $k$ is the shear modulus, $j$ is the shear deformation, and $i$ is the slip at interface.

To calculate the total reaction forces experienced by the tire when contacting soil, the shear and normal stresses can be integrated along the tire's casing. If the deformed tire is assumed to take the shape in Fig. 6, it can be separated into three sections: front circular arc of the tire, flat horizontal section at the bottom of the tire (the depth at which the tire total pressure matches the soil pressure), and rear circular arc of the tire. Tire sinkage and deformation are therefore defined by the angles $\theta_{c}, \theta_{f}$, and $\theta_{r}$.

The net vertical force may then be mathematically expressed as

$$
\begin{aligned}
V= & w R \int_{\theta_{c}}^{\theta_{f}}[p(\theta) \cos (\theta)+s(\theta, i) \sin (\theta)] d \theta+w 2 R P_{t} \sin (\theta) \\
& \left.+w R \int_{\theta_{c}}^{\theta_{r}}[p(\theta) \cos (\theta)-s(\theta, i) \sin (\theta)] d \theta\right]
\end{aligned}
$$

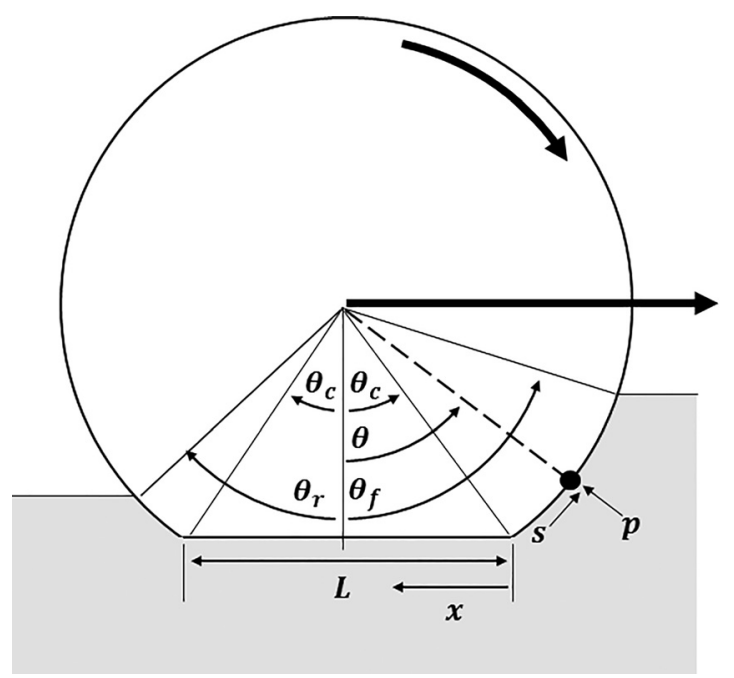

Fig. 6 Parameters of tire perimeter for calculation of forces at soil interface 
The horizontal force is expressed as

$$
\begin{aligned}
H= & w R \int_{\theta_{c}}^{\theta_{f}}[-p(z) \sin (\theta)+s(\theta, i) \cos (\theta)] d \theta+w \int_{0}^{L\left(\theta_{c}, R\right)} s(\theta) d x \\
& \left.+w R \int_{\theta_{c}}^{\theta_{r}}[p(\theta) \sin (\theta)+s(\theta, i) \cos (\theta)] d \theta\right]
\end{aligned}
$$

For both equations, $H$ is the drawbar pull, $V$ is the vertical ground reaction, $w$ is the tire width, $R$ is the tire radius, $p$ is the soil normal stress, $s$ is the soil shear stress, $z$ is the maximum depth of the tire into soil, and $L$ is the length of the tire's deformed flat section. The angles $\theta_{c}, \theta_{f}$, and $\theta_{r}$ define the tire shape and sinkage into the soil (Fig. 6).

All tires are assumed to be rigid $\left(\theta_{c}\right.$ is zero) if the maximum soil normal pressure $p$ exerted on them is less than the sum of the tire carcass stiffness and the tire inflation pressure. Once the tire has sunk into the soil (depth $z$ ) to the point where the soil normal pressure $p$ exceeds the tire inflation pressure and carcass stiffness, it is assumed the tire starts deforming and soil depth $z$ remains constant (i.e., $\theta_{c}$ grows to support the extant vertical load, see Fig. 6).

It is often the case that nominal reaction forces at the tires are known but not the tire sinkage, deformation, and slippage- these are needed to solve for power consumption and maximum drawbar pull. These values must first be solved for idle wheels to find their horizontal force $H$, which will oppose vehicle motion and must be overcome by driven wheels.

Slippage $i$ is assumed to be zero for tires that are idle (are not driven) and thus the soil shear strength $s(i)$ terms in Eqs. (6) and (7) are zero. In this case, only the angles $\theta_{c}, \theta_{f}$, and $\theta_{r}$ must be solved for. These are found by allowing the tire to sink into the soil until the vertical load on that tire matches the soil reaction $V$ from Eq. (6). All values are now known to calculate from Eq. (7) the horizontal force $H$ on the tire (which will be negative and opposing vehicle motion in this case).

For the driven wheels, an optimization routine must be implemented to simultaneously solve for slippage $i$ as well as the tire deformation and sinkage parameters $\theta_{c}, \theta_{f}$, and $\theta_{r}$. This is achieved by finding the solution that minimizes the power consumed at the wheel while maintaining force equilibrium (vertical load at the tire is equal to $V$ from Eq. (6) and horizontal load is equal to $H$ from Eq. (7)).

3.4 Validation of Tractor Model With Published Data. To verify the model's accuracy as implemented, in this section, its outputs are compared to published data on production tractors. Experimental data were obtained from Battiato, Diserens, and Sartori $[43,44]$, where four different sized production tractors were tested in various soil conditions. To test a tractor's drawbar pull performance, it towed a braking tractor behind it via an instrumented cable. The braking tractor was set to generate only the desired horizontal drawbar pull force on the tractor being evaluated. The pulling cable attachment height matched the CG height of the tractor being evaluated. The model shows good agreement with the experimental data (Fig. 7).

\section{Results and Discussion: Analytical Model Insights Into Tractor Dominant Design}

This section summarizes, based on governing physics, why the dominant tractor design is a viable engineering product.

4.1 Advantages of Conventional Tractor Weight Distribution. Modeling (Fig. 8) and historical data (Fig. 9) show that drawbar performance is maximized by placing 70 to $80 \%$ of the tractor's weight on the rear wheels. Shifting the center of mass forward reduces pulling capacity while shifting it backward

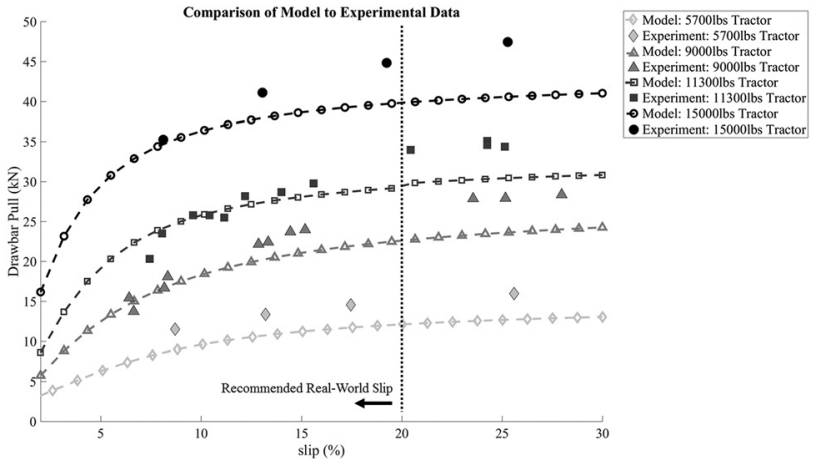

Fig. 7 Comparison of tractor model as described in Sec. 3 to published tractor experiments. Experimental data from work of Battiato, Diserens, and Sartori $[43,44]$. Model has its best accuracy between $5 \%$ and $20 \%$ slip, which is the range recommended for farm tractor operation [38-40,45].

produces a negligible increase in pulling capacity but dangerously increases the risk of upending the tractor.

Figure 8 shows modeling results for the effect on tractor pulling performance from weight, weight distribution, and draft magnitude. In Fig. 8, weight distribution is defined as the value when the vehicle is static at zero drawbar pull. The effective weight distribution during operation is accounted for during simulation calculations. Note that when moving along the "Weight distribution on rear axle (\%)" axis, power required to move (color bar value) is reduced by shifting weight backward until it asymptotes at around $70 \%$ of the tractor weight on back wheels.

The historical data in Fig. 9 were obtained from the Nebraska Tractor Test archives [36]. These tests are a standardized method to evaluate the performance of farm tractors. Test results are public and often used by manufacturers when promoting their tractors. For the manufacturers, one of the more marketable parts of the test involves the maximum generated drawbar pull force when towing a braked vehicle behind the tractor. Before 1950, the tests were performed on soil instead of the concrete track now used. Farm tractors below $25 \mathrm{hp}$ tested between 1941 and 1950 (Fig. 9) were selected for comparison to the trends established in Fig. 8.

For the Nebraska Tractors Tests, engineers employed by the manufacturer whose tractor was being tested were allowed to ballast their vehicles as they preferred before testing began. The preferred setups provide valuable insight into what adjustments the company's engineers believed would maximize their tractor's

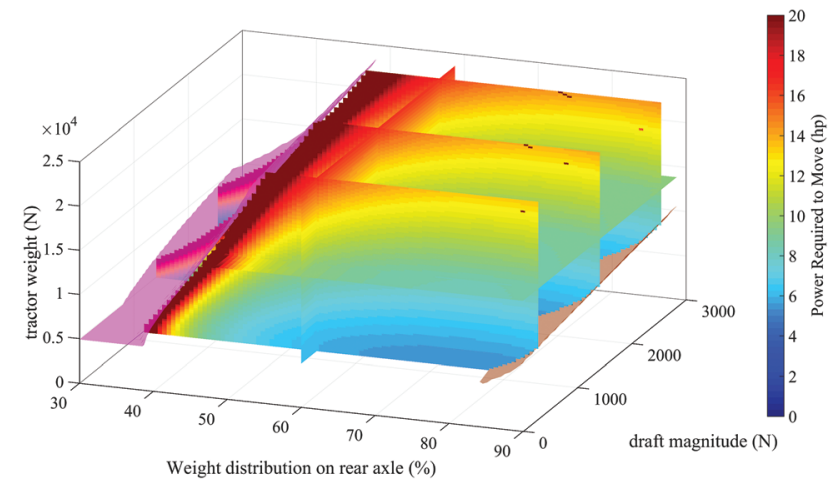

Fig. 8 Simulation data for tractor configurations with varying weight, weight distribution, and draft load demonstrate that optimal weight distribution for drawbar pull is $70-80 \%$ of vehicle mass on the rear wheels. The semitransparent purple frontier on the left represents where tractor wheels slip fully without generating progress or where any wheel sinks past its radius. The semitransparent brown frontier on the right represents when the tractor upends and flips backward. 

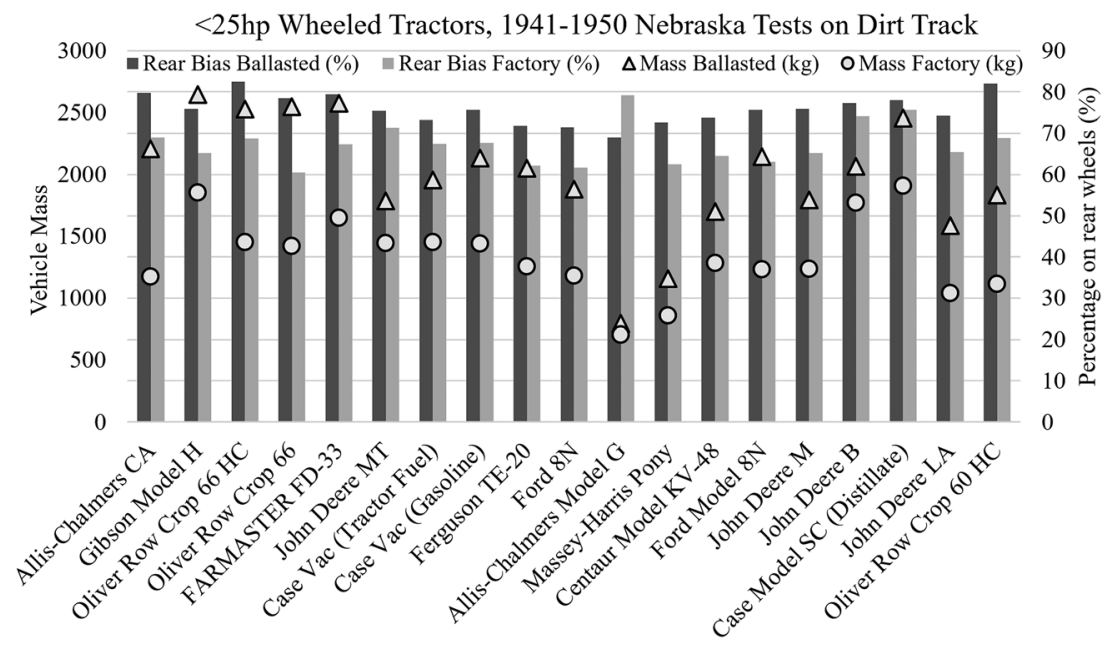

Fig. 9 Data compiled from Nebraska tractor test archives [44]. A highly publicized part of the Nebraska test measures maximum drawbar pull; this table shows how engineers would set up their vehicles for the test. Notice that, in an effort to maximize performance, company engineers would ballast their tractors to have about $70-80 \%$ of the total vehicle mass on the rear wheels.

performance. In Fig. 9, it can be observed that the engineers would generally set up their tractors to maximize drawbar performance by increasing vehicle mass and placing 70 to $80 \%$ of the tractor's total weight on the rear wheels. These adjustments are supported by the findings in the Sec. 3 model.

4.2 Advantages of Tillage Tool Rigid Mounting Behind the Rear Axle. Rigidly mounting heavy tillage tools behind the rear axle is a major characteristic of the dominant tractor design. The utilization of draft forces to increase the vertical load on the rear wheels (and thus the maximum drawbar pull) was a critical enabler to reducing the size and cost of tractors to the point where they could be a general purpose tool for the common farmer. From the free body diagram (Fig. 4) and the terramechanics theory in Sec. 3, the following observations are made about rear tool mounting: it is efficient for tillage, it is convenient for the user, and it facilitates manufacturing. A background on the introduction of this "Three Point Hitch" mounting style is given in Sec. 2.4.

The maximum pulling force the tractor can produce increases approximately constantly with the tillage tool draft force $D$. As seen in Fig. 4, tillage tool draft force $D$ generates a net moment on the tractor-the backward component of $D$ acts on the relatively short lever arm $Y_{D}$, while the downward component acts on the longer lever arm $X_{D}$. The net moment wants to lift the front end wheels off the ground. This increases the vertical load on the rear wheels $V_{r}$, which augments the soil's shear strength and thus the traction force $H_{r}$ generated at a given soil-tire slip. It also reduces the vertical load on the front wheels $V_{f}$, reducing soil bulldozing force $B_{f}$ due to tire sinkage (Fig. 10).

Mounting the farming implement on a hydraulically actuated rear hitch is practical and safe for the operator. The driver need only reverse the implement-less tractor toward an implement, lock the implement attachment points, and drive away. Placing the implement behind the rear axle does not directly constrain the length or width of the implement since the tractor tires will not physically interfere with the implement or immediately drive over soil that the implement has already worked on. This in an important advantage for more powerful tractors that can pull several ground engaging "bottoms" at once. Finally, the driver is physically safe from the implement behind them while driving the tractor. This can be especially important for implements that have moving parts powered by the engine or that launch significant amounts of debris.
Placing the implement (tillage tool) behind the rear axle can facilitate manufacturing via beneficial component packaging and a short load path between the traction gear and tool. The drive axle, hydraulics, and PTO shaft are all around the same location where engine power is being delivered (thus creating a short load path between heavy drawbar pull tools and the tractor's driven tires). Additionally, the space behind the rear axle can be fully dedicated to the implement, its attachment linkages, and its power sources (hydraulics and PTO). This setup also allows placing the engine over the front wheels and using the drivetrain's transmission case and crank case as the structural "frame" of the tractor, which minimizes the amount of components, facilitates fabrication, and reduces mass. This method of construction was critical to helping Henry Ford create farm tractor assembly lines [9].

4.3 Advantages of Conventional Rear Wheel Drive. Driven side-by-side rear wheels connected via a differential axle are well suited for farm tractors-some of their advantages are tight turning, simple construction, and being able to leverage trailing tool forces for improved performance.

Tight turning is a feature of the conventional layout for two main reasons: a large steering angle enabled by small radii front wheels and the ability to independently brake each rear wheel.

Tractor construction was simplified by side-by-side rear drive wheels since it allowed use of a standard differential axle (as also engineered for emerging automobiles) and required less structural reinforcements. If front (steered) wheels are driven, additional linkages must be added to the driveline to enable steering. Since most heavy draft implements are attached closely behind the rear axle, the tractor load path from the rear wheels' traction force to the implement attachment points is short and most of the tractor's structure need not be reinforced to support the tool's loads.

A tillage tool attached behind the tractor will cause the effective weight distribution of the tractor to shift rearward. This added vertical load on the rear wheels can increase their maximum tractive force as supported by production vehicle data [46] and modeling.

4.4 Advantages of Four Wheel Rectangular Layout. A four wheel rectangular layout is sound from a manufacturing, stability, and terramechanics perspective. By rectangular, it is meant that the front and rear axle dimensions allow the rear wheels to run over the "ruts" or "tracks" formed by the front wheels. In other 
words, both right wheels are longitudinally in line with each other, as are the left wheels. More than four wheels would increase manufacturing and maintenance complexity (and cost). Fewer than four wheels decreases the stability of the tractor $[47,48]$.

There are two key advantages of a rectangular wheel layout from a terramechanics perspective: improved crop yields and better tractive efficiency. It is less detrimental to crop yields to drive over the same patch of soil in the field multiple times (as is the case with inline front and rear wheels) than it is to drive over more areas of soil on the field only once. Applying this when planning routes for field operations is called "Controlled Traffic" and has been proven beneficial in farm fields across the world [49-54]. Each tire pass strengthens (compacts) the patch of soil it runs on, making it a better rolling surface for trailing tires. This means the idle front wheels can partially "precompact" the soil for the driven rear wheels, thus improving the vehicle's maximum drawbar pull and tractive efficiency $[39,55,56]$.

\section{Conclusions}

This research paper describes how the dominant farm tractor design evolved mostly in the U.S. between 1910 and 1940. It provides a historical reflection on the priorities that drove the creation of the tractor. It also uses engineering analysis to justify why the conventional tractor design is well suited to farming and has endured the test of time.

The conventional farm tractor evolved not only to maximize farming performance but also to satisfy intense pressures from the social and political context it developed in. In particular, an unpredictable economic backdrop and sharing engineering with the new automotive industry rapidly pushed the tractor industry toward standardization and competitively priced mass manufactured vehicles by a few large corporations.

The conventional farm tractor has a sensible design that is easy to use, easy to manufacture, and offers efficient performance. In particular, at least within the constraints of its standard overall layout, it has nearly optimal weight distribution and tillage tool attachment.

Contemporary engineers may wish to use this paper to explore which features of the existing dominant tractor design are applicable to their own novel tractor layout implementations. Consider that the dominant tractor design evolved mostly in the U.S. between 1910 and 1940 and is sold worldwide today; however, during that period, and since, American farms have been about
100 times larger than at least $80 \%$ of today's farms globally [55-58]. As mechanization increases in developing and emerging markets, engineers may question if the dominant tractor design is the ideal one to sell to these small farms. At possibly a different end of the price spectrum, new technologies like autonomous driving may enable design freedoms for modern tractors that were not available in the 1940s. This paper provides insights on tractor features that enhance user comfort and farming productivity, as well as the physics behind tractor performance, which may be of value to engineers designing new farming equipment for developing and developed markets around the globe.

\section{Acknowledgment}

Thank you to Gwyndaf Jones for sharing with us his vintage tractor knowledge and book collection.

$$
\begin{aligned}
& \text { Nomenclature } \\
& B=\text { soil bulldozing force } \\
& c=\text { soil cohesion } \\
& D=\text { draft force } \\
& F=\text { pulling force generated by tire } \\
& H=\text { tractor traction thrust force } \\
& i=\text { slip at tire-soil interface } \\
& j=\text { soil shear deformation } \\
& k=\text { soil shear modulus } \\
& k_{c}^{\prime}=\text { cohesion constant } \\
& k_{\phi}^{\prime}=\text { friction constant } \\
& n=\text { depth exponent } \\
& p=\text { soil (normal) pressure } \\
& P=\text { power delivered to wheel } \\
& P_{t}=\text { net tire pressure } \\
& P_{t}=\text { tire pressure } \\
& R=\text { tire outer radius at contact point } \\
& s=\text { soil shear strength } \\
& S=\text { actual forward speed of vehicle } \\
& V=\text { vertical soil reaction force } \\
& w=\text { tire width } \\
& W=\text { weight } \\
& z=\text { depth below the surface } \\
& \gamma_{s}=\text { soil bulk density } \\
& \eta=\text { tractive efficiency } \\
& \phi=\text { soil friction angle }
\end{aligned}
$$

\begin{tabular}{|c|c|c|c|c|c|}
\hline Layout & Manufacturer & Model & Years & Engine (hp) & Mass (kg) \\
\hline $\mathrm{A}$ & $\begin{array}{c}\text { Twin City (Minneapolis, MN) } \\
\text { Russell (Massillon, OH) } \\
\text { Huber (Marion, OH) }\end{array}$ & $\begin{array}{c}12 / 20 \\
\text { Model C 20/40 } \\
30 / 60\end{array}$ & $\begin{array}{l}1919-1926 \\
1919-1924 \\
1912-1916\end{array}$ & $\begin{array}{l}27 \\
40 \\
60\end{array}$ & $\begin{array}{l}2268 \\
3450 \\
5000\end{array}$ \\
\hline B & $\begin{array}{c}\text { Hart-Parr (Charles City, IA) } \\
\text { Samson (Stockton, CA) } \\
\text { Wallis (Racine, WI) }\end{array}$ & $\begin{array}{l}20-40 \\
\text { Sieve Grip } \\
\quad \text { Cub }\end{array}$ & $\begin{array}{l}1912-1914 \\
1914-1918 \\
1913-1917\end{array}$ & $\begin{array}{l}40 \\
25 \\
44\end{array}$ & $\begin{array}{l}6000 \\
2630 \\
3855\end{array}$ \\
\hline $\mathrm{C}$ & $\begin{array}{l}\text { Bull (Minneapolis, MN) } \\
\text { Case (Racine, WI) }\end{array}$ & $\begin{array}{l}\text { Little Bull } \\
10 / 20\end{array}$ & $\begin{array}{l}1913-1915 \\
1914-1918\end{array}$ & $\begin{array}{l}12 \\
20\end{array}$ & $\begin{array}{l}1800 \\
2304\end{array}$ \\
\hline $\mathrm{D}$ & $\begin{array}{c}\text { Hart-Parr } \\
\text { Common Sense } \\
\text { Emerson Brantingham }\end{array}$ & $\begin{array}{l}\text { Little Devil } \\
15 / 25 \\
\text { Model L }\end{array}$ & $\begin{array}{l}1914-1916 \\
1914-1918 \\
1916-1918\end{array}$ & $\begin{array}{l}22 \\
25 \\
20\end{array}$ & $\begin{array}{l}3015 \\
2700 \\
2500\end{array}$ \\
\hline
\end{tabular}

\section{Appendix A: List of 1910-1920 Production Vehicles Representing Different Layouts}

The vehicles in Table 1 are matched to Layouts Discussed in Fig. 2 of Sec 2. It is the authors' intent that Table 1 will help engineers match a layout of interest to a production vehicle for which they could find more details and images in other published resources.

Table 1 Specifications for tractors in Fig. 2 of Sec. 2 
Table 1 (Continued)

\begin{tabular}{|c|c|c|c|c|c|}
\hline Layout & Manufacturer & Model & Years & Engine (hp) & Mass (kg) \\
\hline $\mathrm{E}$ & Gray Tractor (Minneapolis, MN) & Model B & 1914-1918 & 25 & 2500 \\
\hline $\mathrm{F}$ & Joliet (Joliet, IL) & Bates Steel Mule F & 1915-1937 & 30 & 2200 \\
\hline G & $\begin{array}{c}\text { Beltrail (St. Paul, MN) } \\
\text { Tom Thumb (Minneapolis, MN) } \\
\text { Joliet }\end{array}$ & $\begin{array}{c}\text { Model B 12-20 } \\
12-20 \\
\text { Bates Steel Mule C }\end{array}$ & $\begin{array}{l}1917-1920 \\
1917-1920 \\
1911-1919\end{array}$ & $\begin{array}{l}20 \\
20 \\
30\end{array}$ & $\begin{array}{l}1500 \\
1900 \\
2200\end{array}$ \\
\hline $\mathrm{H}$ & $\begin{array}{c}\text { Yuba (Yuba City, WA) } \\
\text { Blewett (Tacoma, WA) } \\
\text { Holt (Stockton, CA) }\end{array}$ & $\begin{array}{c}20-35 \\
\text { Webfoot } 53 \\
75\end{array}$ & $\begin{array}{l}1911-1916 \\
1920-1922 \\
1913-1924\end{array}$ & $\begin{array}{l}35 \\
53 \\
75\end{array}$ & $\begin{array}{r}3500 \\
4500 \\
10,432\end{array}$ \\
\hline I & Killen Strait (Appleton, WI) & $30 \mathrm{hp}$ & $1917-1919$ & 30 & 2600 \\
\hline $\mathrm{J}$ & Killen Strait & $15-30$ & $1913-1917$ & 30 & 4300 \\
\hline K & $\begin{array}{c}\text { Lawter (St. Mary's, OH) } \\
\text { Boring (Rockford, IL) } \\
\text { Hackney (Minneapolis, MN) }\end{array}$ & $\begin{array}{c}18 / 38 \\
12 / 25 \\
\text { Auto-Plow }\end{array}$ & $\begin{array}{l}1914-1918 \\
1916-1922 \\
1916-1922\end{array}$ & $\begin{array}{l}38 \\
25 \\
36\end{array}$ & $\begin{array}{l}2950 \\
2050 \\
3630\end{array}$ \\
\hline $\mathrm{L}$ & $\begin{array}{l}\text { S. L. Allen (Philadelphia, PA) } \\
\text { Moline (Moline, IL) } \\
\text { Allis-Chalmers (West Allis, WI) }\end{array}$ & $\begin{array}{l}\text { Planet Jr. } \\
\text { Universal } \\
6-12\end{array}$ & $\begin{array}{l}1920-1935 \\
1914-1918 \\
1919-1926\end{array}$ & $\begin{array}{l}2.31 \\
27 \\
12\end{array}$ & $\begin{array}{r}250 \\
1630 \\
1134\end{array}$ \\
\hline M & Acme (Brevard, NC) & $12-24$ & $1918-1919$ & 24 & 1450 \\
\hline $\mathrm{N}$ & Rumely (La Porte, IN) & $8-16$ & $1917-1919$ & 16 & 2600 \\
\hline $\mathrm{O}$ & Victor (Marion, $\mathrm{OH}$ ) & Victor & 1919 & 34 & 1950 \\
\hline $\mathrm{P}$ & Bean (San Jose, CA) & Track-Pull 6/10 & $1918-1920$ & 10 & 1400 \\
\hline Q & $\begin{array}{c}\text { Samson } \\
\text { Olmstead (Great Falls, MT) }\end{array}$ & $\begin{array}{l}\text { Iron Horse D } \\
\text { Four Wheel Pull }\end{array}$ & $\begin{array}{l}1918-1923 \\
1914-1920\end{array}$ & $\begin{array}{l}26 \\
50\end{array}$ & $\begin{array}{r}850 \\
3000\end{array}$ \\
\hline $\mathrm{R}$ & Fitch Four Drive (Ludington, MI) & $20 / 30$ & $1915-1918$ & 30 & 1360 \\
\hline S & Buckeye (Anderson, IN) & Junior & $1912-1915$ & 25 & 2500 \\
\hline $\mathrm{T}$ & $\begin{array}{l}\text { Heer (Portsmouth, OH) } \\
\text { Nelson (Boston, MA) }\end{array}$ & $\begin{array}{l}20-28 \\
20-28\end{array}$ & $\begin{array}{l}1912-1916 \\
1917-1924\end{array}$ & $\begin{array}{l}30 \\
30\end{array}$ & $\begin{array}{l}2000 \\
2000\end{array}$ \\
\hline $\mathrm{U}$ & Rumely & Ideal pull & $1916-1917$ & 16 & 1500 \\
\hline V & Post (Cleveland, $\mathrm{OH})$ & $12-20$ & $1918-1920$ & 20 & 1500 \\
\hline $\mathrm{W}$ & John Deere (Moline, IL) & Dain & 1918-1919 & 24 & 2086 \\
\hline $\mathrm{X}$ & Bullock (Davenport, IA) & Creeping grip & 1916-1919 & 20 & 3270 \\
\hline
\end{tabular}

\section{Appendix B: Production Vehicles Representative of Major Evolutionary Steps}

Table 1 is matched to vehicles in Fig. 3 of Sec. 2. It is the authors' intent that Table 2 will provide engineers with context to better understand the tractors studied.

Table 2 Specifications for tractors in Fig. 3 of Sec. 2

\begin{tabular}{|c|c|c|c|c|c|c|}
\hline Manufacturer & Model & Years & Engine (hp) & Mass (kg) & Price (2017) & Units made \\
\hline Ivel & "tractor" & 1902-1920 & 18 & 1814 & $£ 300(\$ 43,630)$ & 900 \\
\hline Hart-Parr & $30-60$ & 1907-1918 & 60 & 9120 & $\$ 2600(\$ 64,030)$ & 3798 \\
\hline Ford & $\mathrm{T}$ & 1908-1927 & 22 & 660 & $\$ 360(\$ 5067)$ & $14,689,525$ \\
\hline Avery & Farm and City & 1909-1915 & 36 & 2100 & $\$ 2500(\$ 67,750)$ & - \\
\hline Bull & Little Bull & 1913-1915 & 12 & 1315 & $\$ 335(\$ 8450)$ & 3800 \\
\hline Wallis & $\mathrm{Cub}$ & 1914-1918 & 44 & 3855 & $\$ 2480(\$ 55,495)$ & 660 \\
\hline Moline & Universal & 1915-1918 & 27 & 1630 & $\$ 1325(\$ 18,105)$ & 20,000 \\
\hline Nilson & $20-40$ & 1916-1929 & 40 & 2380 & $\$ 925(\$ 33,230)$ & - \\
\hline Square turn & $18-35$ & 1917-1925 & 35 & 3538 & $\$ 1875(\$ 22,900)$ & approx.700 \\
\hline Fordson (Ford) & $\mathrm{F}$ & 1917-1928 & 20 & 1215 & $\$ 395(\$ 5760)$ & 755,278 \\
\hline Int. Harvester & $15-30$ & 1921-1928 & 30 & 2653 & $\$ 1250(\$ 17,905)$ & 157,366 \\
\hline Int. Harvester & Farmall Reg. & 1924-1932 & 20 & 1655 & $\$ 925(\$ 13,530)$ & 134,647 \\
\hline Allis-Chalmers & $\mathrm{U}$ & 1929-1952 & 20 & 2086 & $\$ 125(\$ 21,240)$ & 19,009 \\
\hline Ford & $9 \mathrm{~N}$ & 1939-1942 & 20 & 970 & $\$ 585(\$ 10,291)$ & 99,002 \\
\hline
\end{tabular}



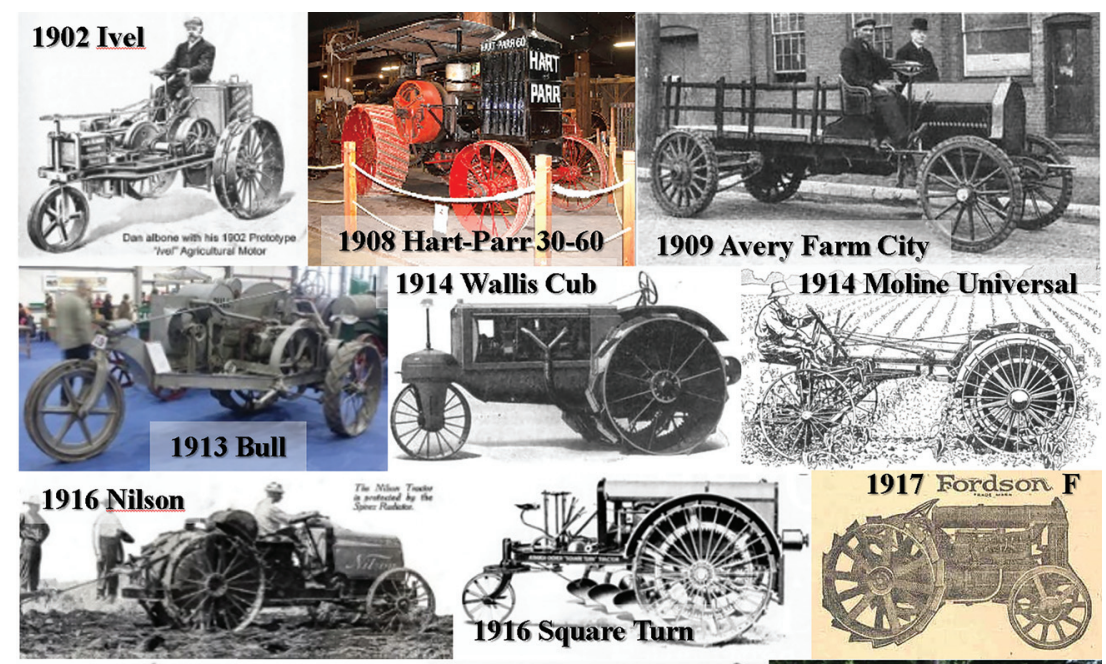

1917 Fordson F
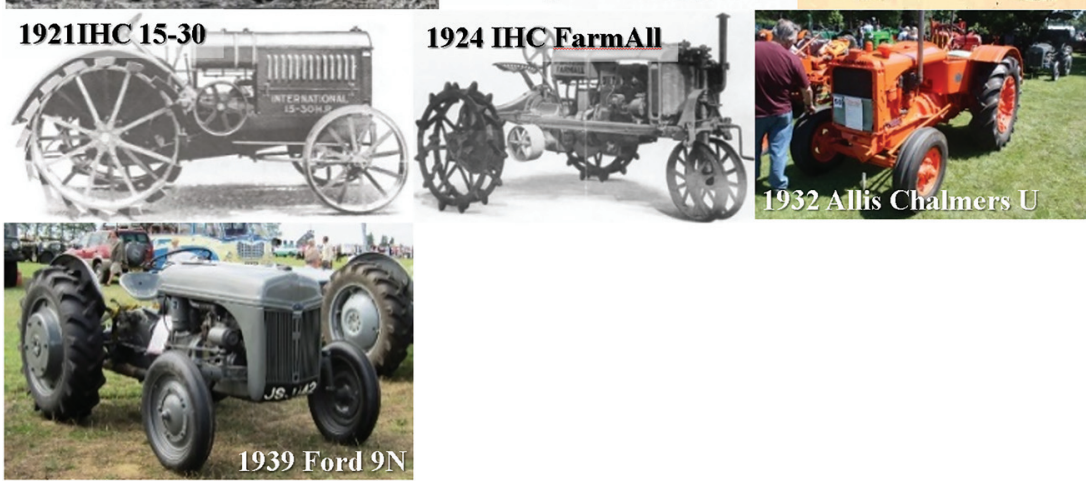

Fig. 10 Larger images of tractors in Fig. 3 of Sec. 2

\section{References}

[1] Foster, A., and Rosenzweig, M. R., 2010, "Barriers to Farm Profitability in India: Mechanization, Scale and Credit Markets," World Bank University California Berkeley Conference Agricultural Devolpment, Berkeley, CA.

[2] FAO, 1985, "FAO, the First 40 Years: 1945-1985," Food and Agricultural Organization, Rome, Italy.

[3] FAO, 2013, "Mechanization for Rural Development: A Review of Patterns and Progress From Around the World," Integrated Crop Management, Food and Agricultural Organization, Rome, Italy

[4] Srivastava, N. S. L., 2006, "Farm Power Sources, Their Availability and Future Requirements to Sustain Agricultural Production," Indian Council of Agricultural Research, New Delhi, India.

[5] Spoor, G., Carillon, R., Bournas, L., and Brown, E. H., 1987, The Impact of Mechanization, Wiley, Chichester, NY

[6] U.S. Census Bureau, 1950, "Agriculture 1950: Changes in Agriculture, 1900 to 1950," U.S. Census Bureau, Suitland, MD.

[7] Wood, A. E., and Mattson, C. A., 2016, "Designing for the Developing World: Common Pitfalls and How to Avoid Them," ASME J. Mech. Des., 138(3), p. 031101

[8] Xiong, Y., Tian, L., Ahamed, T., and Zhao, B., 2012, "Development of the Reconfigurable Data Acquisition Vehicle for Bio-Energy Crop Sensing and Management," ASME J. Mech. Des., 134(1), p. 015001.

[9] Williams, R. C., 1987, Fordson, Farmall, and Poppin' Johnny: A History of the Farm Tractor and Its Impact on America, University of Illinois Press, Champaign, IL.

[10] Olmstead, A. L., and Rhode, P. W., 2001, "Reshaping the Landscape: The Impact and Diffusion of the Tractor in American Agriculture, 1910-1960," J. Econ. Hist., 61(3), pp. 663-698.

[11] Marshaus, S., 2015, "Dominant Design: How the Ferguson System Revolutionized Mechanized Agriculture," Master's thesis," University of Wisconsin-Eau Claire, History Department, Eau Claire, WI

[12] White, W. J., 2018, "Economic History of Tractors in the United StatesEconomic History Association," Economic History Association, La Crosse, WI, accessed June 5, 2018, https://eh.net/encyclopedia/economic-history-of-tractorsin-the-united-states/

[13] Ivel, 1903, "Tractor 1902," Originally Published in North Berdfordshire Gazzette (Bedfordshire, UK), accessed Feb. 15, 2019, https://commons.wikimedia.org/ wiki/File:Ivel_Tractor_1902.JPG

[14] Zell, H., 2016, "Hart-Parr 30-60 (1916).jpg," Photograph by H. Zell (a.k.a Llez) a Wikimedia Contributor from Germany,ûÂ̂ô Under GNU Free Documentation License and Creative Commons Attribution-Share Alike 3.0 Unported license, accessed Feb 15, 2019, https://commons.wikimedia.org/wiki/File:HartParr_30-60_(1916).jpg

[15] Engineering and Contracting, 1909, "Image in Public Domain," The Horseless Age Co, New York, accessed Jan 8, 2019, https://babel.hathitrust.org/cgi/ pt?id=mdp.39015073286851; view=1 up;seq=112

[16] BulldozerD11, 2008, “Little Bull - 5-12 of 1914 no. 910 at Newark VTS 08," Image taken at "Newark Vintage Tractor Show" in the year 2008 in location Newark, Nottinghamshire, UK, accessed Feb. 15, 2019, http://tractors.wikia. com/wiki/File:Little_Bull_-_5-12_of_1914_no._910_at_Newark_VTS_08_IMG_3746.jpg

[17] Wallis Tractor Company, 1916, The Tractor Field Book: With Power Farm Equipment Specifications, Farm Implement News Company, Chicago, IL, p. 55.

[18] Gas Power, 1924, "Moline Plow Company advertisement for the Moline Universal Tractor," Gas Power, accessed Feb. 15, 2019, https://commons.wikimedia.org/wiki/ File:Moline_Universal_Tractor_advert_1918.png

[19] Country Gentleman Magazine, 1918, Image by Modine Spirex Radiators of Racine, WI, USA. Published in May 18, 1918 issue of the "Country Gentleman Magazine," which was based in Rochester, NY, USA. Image in public domain.

[20] Square Turn Tractor Company, 1916, "Advertisement," Image From Pamphlet Produced by 'Square Turn Tractor Company' in Norfolk, NE, USA to Advertise Their Product, Square Turn Tractor Company, Norfolk, NE.

[21] Fordson, F., 1917, "Wade and Dunton Motors Advertisement," Wade and Dunton Motors, Lewinston, ME.

[22] International Harvester Company, 1920, "Instructions for Operating the McCormick-Deering 15-30 H.P. Gear Drive Tractor," International Harvester Company, Chicago, IL.

[23] Edrob, 2010, "McCormick Deering FarmAll Tractor," tractors.wikia.com, Orig inally published in 1924 ad by McCormick International Harvester in Chicago, IL, accessed Feb. 15, 2019, http://tractors.wikia.com/wiki/File:McCormickDeering_Farmall_1925.jpg

[24] BulldozerD11, 2009, "Woolpit Steam Rally," tractors.wikia.com, in Wetherden, Suffolk, UK, accessed Feb. 15, 2019, http://tractors.wikia.com/wiki/ File:Allis-Chalmers_Model_U_sn_\%3F_of_1939_at_Woolpit_09_-_IMG_1287. jpg

[25] Charles01, 2011, "Ford Ferguson 9N tractor 1942," accessed Feb. 15, 2019 https://commons.wikimedia.org/wiki/File:Ford_Ferguson_9N_tractor_1942.jpg

[26] Federico, G., 2005, "Not Guilty? Agriculture in the 1920s and the Great Depression," J. Econ. Hist., 65(4), pp. 949-976.

[27] Eason, C. M., 2015, "Tendency of Farm Tractor Design," Trans. Am. Soc. Agric. Eng., 9(1), pp. 59-67

[28] Olney, R., 1918, "Signs of Progress in the Farm Tractor Field," Power Farm ing, The Power Farming Press, St. Joseph, MI, pp. 9-11. 
[29] Yerkes, A. P., and Mowry, H., 1915, "Farm Experiences With the Tractor," USDA Bulletin No. 174, Government Publishing Office, Washington, DC, pp. 4-9.

[30] Ellis, L. W., 1913, "The Problem of the Small Farm Tractor," Scientific American, Munn \& Co., New York, pp. 518-519; 525-528.

[31] Yerkes, A. P., and Church, L., 1918, "The Gas Tractor in Eastern Farming," Farmer's Bulletin 1004, United States Department of Agriculture, Washington, DC

[32] Gray, R., 1954, The Agricultural Tractor, American Society of Agricultural Engineers, St. Joseph, MI, pp. 1855-1950.

[33] Kudrle, R., 1975, Agricultural Tractors: A World Industry Study, Ballinger Publishing Company, Cambridge, MA.

[34] Nebraska Tractor Test Lab, 2018, "Nebraska Tractor Test Laboratory Test Reports," Nebraska Tractor Test Lab, Lincoln, NE, accessed June 5, 2018, https://tractortestlab.unl.edu/

[35] Udengaard, M., and Iagnemma, K., 2009, "Analysis, design, and Control of a Omnidirectional Mobile Robot in Rough Terrain," ASME J. Mech. Des., 131(12), p. 121002.

[36] Cassidy, W. W., 2017, "Tractor Tire and Ballast Management," University Extension, University of Missouri, Columbia, MO

[37] Wong, J., 2010, Terramechanics and Off-Road Vehicle Engineering, Elsevier, Oxford, UK

[38] Smith and Grisso 1990, "Using Tillage Horsepower More Efficiently: Selecting Speed, Slip and Ballast," Conservation Tillage Proceeding, Lincoln, NE, Mar., pp. 79-81.

[39] Bekker, M. G., 1956, Theory of Land Locomotion, University of Michigan Press, Ann Arbor, MI.

[40] Wong, J. Y., and Reece, A., 1967, "Prediction of Rigid Wheel Performance Based on the Analysis of Soil-Wheel Stresses-Part I: Performance of Driven Rigid Wheels," J. Terramechanics, 4(1), pp. 81-98.

[41] Battiato, A., and Diserens, E., 2013, "Influence of Tyre Inflation Pressure and Wheel Load on the Traction Performance of a $65 \mathrm{~kW}$ MFWD Tractor on a Cohesive Soil," J. Agric. Sci., 5(8), pp. 197-215.

[42] Battiato, A., Diserens, E., and Sartori, L., 2013, "Traction Performance Simulation for Mechanical Front Wheel Drive Tractors: Towards a Practical Compute Tool," J. Agric. Eng., XLIV(s2)(7), pp. 338-343.

[43] Engineers at Mahindra and Mahindra Co., 2016, "Conversations With Mahindra and Mahindra Tractor Company on Tractor Adoption in India," Engineers at Mahindra and Mahindra, Chennai, Tamilnadu.

[44] Arelekatti, V. N. M., Björkdal, D. H., Graves, C. W., Wong, A., Mkrtchyan, A., and Winter, A. G., 2014, "Proof-of-Concept Evaluation of a Low-Cost and LowWeight Tractor for Small-Scale Farms,” ASME Paper No. DETC2014-35115.
[45] Demsar, I., Bernik, R., and Duhovnik, J., 2012, "A Mathematical Model and Numerical Simulation of the Static Stability of a Tractor," Agric. Conspec. Sci. 77(3), pp. 143-150

[46] Smith, D. W., 2005, "Safe Tractor Operation: Rollover Prevention," Texas Agricultural and Mechanical University. AgriLife Extension, College Station, TX.

[47] Valera, D. L., Gil, J., and Agäera, J., 2012, "Design of a New Sensor for Determination of the Effects of Tractor Field Usage in Southern Spain: Soil Sinkage and Alterations in the Cone Index and Dry Bulk Density," Sensors, 12(10), pp. 13480-13490.

[48] Antille, D. L., Bennett, J. M., and Jensen, T. A., 2016, "Soil Compaction and Controlled Traffic Considerations in Australian Cotton-Farming Systems," Crop Pasture Sci., 67(1), pp. 1-28.

[49] de Souza, G. S., de Souza, Z. M., da Silva, R. B., Barbosa, R. S., and Araùjo, F. S., 2014, "Effects of Traffic Control on the Soil Physical Quality and the Cultivation of Sugarcane," Rev. Bras. Cuenca Solo, 38(1), pp. 135-146.

[50] Onal, I., 2012, "Controlled Traffic and Widespan Tractors," Tarim Makinalari Bilimi Derg. (J. Agric. Mach. Sci.), 8(4), pp. 353-364.

[51] Chamen, T., 2014, "Controlled Traffic Farming-From Worldwide Research to Adoption in Europe and Its Future Prospects," International Conference of Agricultural Engineering, Zurich, Switzerland, July 6-10, pp. 1-19.

[52] Dejong-Hughes, J., 2017, "Tires, Traction and Compaction," University of Minnesota, Minneapolis, MN.

[53] Ghotbi, B., Gonzàlez, F., Kövecses, J., and Angeles, J., 2015, "Effect of Multi-Pass on the Mobility of Wheeled Robots on Soft Terrain," ECCOMAS Thematic Conference on Multibody Dynamics, Catalonia, Spain, June 29-July 2.

[54] Holm, I., 1969, "Multi-Pass Behaviour of Pneumatic Tires," J. Terramechanics, 6(3), pp. 47-71.

[55] Lowder, S., Skoet, J., and Singh, S., 2014, "What Do We Really Know About the Number and Distribution of Family Farms Worldwide? Background Paper for the State of Food and Agriculture," Rome FAO ESA Working Paper, Agricultural Development Economics Division, Rome, Italy, Paper No. 14-02.

[56] Bureau, U. F. C., 1973, "1969 USA Census of Agriculture," USA Farm Census Bureau, Suitland, MD.

[57] USDA, E. R. S., 2005, "U.S. Farms: Numbers, Size, and Ownership" Structure and Finances of U.S. Farms: 2005 Family Farm Report, U.S. Deparment of Agriculture, Washington, DC, Report No. EIB-12.

[58] MacDonald, J. M., Korb, P., and Hoppe, R. A., 2013, "Farm Size and the Organization of U.S. Crop Farming," USDA Economic Research, Washington, DC, Report No. 152. 